ISSN 1392-3196 / e-ISSN 2335-8947

Zemdirbyste-Agriculture, vol. 108, No. 3 (2021), p. 279-286

DOI 10.13080/z-a.2021.108.036

\title{
Rheological dough properties of organic spelt and emmer wheat for assessment of bread making quality
}

\author{
Magdaléna LACKO-BARTOŠOVÁ ${ }^{1}$, Lucia LACKO-BARTOŠOVÁ ${ }^{1}$, Petr KONVALINA², \\ Eva MATEJKOVÁ ${ }^{3}$, Denisa BIELIKOVÁ ${ }^{1}$
}

${ }^{1}$ Slovak University of Agriculture in Nitra, Faculty of Agrobiology and Food Resources

Tr. A. Hlinku 2, 94976 Nitra, Slovakia

E-mail: lucialbartosova@gmail.com

${ }^{2}$ University of South Bohemia in České Budějovice, Faculty of Agriculture

Branišovská 1645/31a, 37005 České Budějovice, Czech Republic

${ }^{3}$ Slovak University of Agriculture in Nitra, Faculty of Economics and Management

Tr. Andreja Hlinku 2, 94976 Nitra, Slovakia

\begin{abstract}
The aim of this study was to assess the quality of ancient wheat species and to examine the relations between rheological, indirect quality parameters and direct baking test.

Winter spelt (Triticum spelta L.) and winter emmer (Triticum dicoccon Schrank) wheat significantly differ in grain, flour and rheological quality parameters and specific bread volume. It was found that protein quantity, Zeleny index and wet gluten quantity were significantly higher for spelt, but quality of gluten (gluten index) was higher for emmer. Mixolab parameters: speed of protein network weakening (slope $\alpha$ ) and speed of starch gelatinization (slope $\beta$ ) were slower for emmer; starch retrogradation (torque C5) was lower and time of starch gelatinization was longer for emmer. Principal component analysis (PCA) revealed that spelt and emmer wheat were strongly discriminated by the grain quality, farinograph rheological quality, Mixolab parameters and direct baking test. Based on PCA and Pearson's correlation coefficients, specific bread volume of emmer was highly associated with protein weakening (torque $\mathrm{C} 2$ ), farinograph dough stability, dough development time and wet gluten quantity. On the contrary, spelt specific bread volume was associated with Zeleny index and negatively correlated with Mixolab speed of the protein network weakening (slope $\alpha$ ). These parameters are the most promising for the prediction of spelt and emmer bread making quality.
\end{abstract}

Key words: Triticum dicoccon, Triticum spelta, rheological, baking quality, principal component analysis.

\section{Introduction}

Ancient wheat species that have remained unchanged over the last hundred years are gaining interest, since several studies suggested that they present greater health potential for improved antioxidant and anti-inflammatory properties, healthier nutritional profile than modern wheat (Dinu et al., 2018). The most common ancient, hulled wheat species commercially available are einkorn (Triticum monococcum L., diploid, genome AA), emmer (Triticum dicoccon Schrank, tetraploid, genome AABB) and spelt (Triticum spelta L., hexaploid, genome AABBDD) wheat. They represent three cultivated species of hulled wheat, which include a bridging species between the cultivated (bread and durum) and wild wheats (Arzani, Ashraf, 2017). Einkorn and emmer as the first crops domesticated approximately 12000 years ago in the Near East were cultivated on marginal land and were able to survive in harsh climate conditions and poor soils. Spelt is characterised by a greater adaptation to a wider range of environments (Cooper, 2015; Shewry, Hey, 2015; Shewry, 2018). Bread and durum wheat together account for the vast majority of the global wheat production.
Ancient wheat continues to be produced in small amounts and increases in production have occurred in recent years to satisfy the rising demand for the healthier food market. The popularity of particularly spelt has been revived in the last two decades, mainly due to the expansion of organic farming, its lower soil and nutritional requirements, higher tolerance to biotic and abiotic stresses than common wheat for increasing the biodiversity of cultivated cereals (Wolfe et al., 2008; Markowski et al., 2013; Żuk-Gołaszewska etal., 2018; Barański et al., 2020). Ethnographic evidence from Turkey and other emmer wheat growing areas suggests that emmer makes good bread, and this is supported by its widespread consumption as bread in ancient Egypt (Cooper, 2015).

Although consumers are conscious of the relationship between food and health, the benefits of diversified cereal grains in the human diet have not been fully recognized yet. There is a paucity of data on the use of ancient wheat flour as a partial substitute of common wheat flour in making breads, cookies and pasta (Arzani, Ashraf, 2017). The nutritional and phytoprotective value

Please use the following format when citing the article:

Lacko-Bartošová M., Lacko-Bartošová L., Konvalina P., Matejková E., Bieliková D. 2021. Rheological dough properties of organic spelt and emmer wheat for assessment of bread making quality. Zemdirbyste-Agriculture, 108 (3): $279-286$. DOI 10.13080/z-a.2021.108.036 
of non-traditional cereals is higher than that of common wheat, but the rheological properties of dough are still insufficiently investigated (Wiwart et al., 2017).

The evaluation of the flour quality is based on properties determined through the grain indirect baking quality and rheological and technological analyses. Rheological characteristics such as elasticity, viscosity and extensibility are important for the milling and bakery industry used for the prediction of the dough processing parameters and the end-product quality (Jirsa et al., 2007; Śvec, Hrušková, 2015).

The evaluation of flour and dough properties can be conducted by rheological instruments such as farinograph, extensograph, alveograph, mixograph, maturograph, rheofermentometer and consistograph, but they do not evaluate the dough consistency during heating and cooling stages and changes in starch paste associated with thermal processes. The most reliable method is direct baking test; however, it is time-consuming and requires skilled personnel and is difficult to use for commercial purposes. Therefore, other methods are needed to determine the suitability of flour for baking in a shorter period of time (Koksel el al., 2009; Schmiele et al., 2017).

The Mixolab is a rheological device that determines the dough consistency during heating and cooling stages. The apparatus measures both flour protein and starch characteristics and provides information about the dough development time, protein breakdown, starch gelatinization, enzyme activity and the gel strength in a single test (Dubat, 2010). The pasting properties of starch might give useful information related to the quality of bakery products and should be investigated to establish alternative methods for the prediction of baking quality
(Koksel et al., 2009). Mixolab has been applied for prediction and suitability of flours for different end-uses, e.g., the cookie and cake quality (Kahraman et al., 2008; Ozturk et al., 2008), the effect of antioxidants on dough mixing properties (Abdel-Samie et al., 2010), linseed fibre on wheat flour pasting and bread quality (Švec, Hrušková, 2018). The information related to Mixolab use for the evaluation of different aspects of hulled wheat flour quality is very limited (Bernas et al., 2016).

The objectives of this study were: (1) to investigate the technological grain, flour and direct baking quality of ancient wheat species, (2) to test the potential of device Mixolab II in the flour quality assessment of these species, and (3) to examine the relations between indirect technological quality parameters and baking test for the prediction of bread making potential of nontraditional cereals.

\section{Materials and methods}

Field trials and experimental design. Field experiments arranged as randomised blocks in four replicates were conducted in 2013-2015 at the experimental base $\left(48^{\circ} 19^{\prime} \mathrm{N}, 18^{\circ} 07^{\prime} \mathrm{E} ; 177-178 \mathrm{~m}\right.$ a.s.1.) of the Slovak University of Agriculture in Nitra, Slovakia. The experimental area has a continental climate, belongs to a warm agroclimatic region, arid subregion with predominantly mild winters with average long-term (1981-2011) annual precipitation of 541.3 $\mathrm{mm}$. The average long-term temperature is $10.1^{\circ} \mathrm{C}$. The average temperature and precipitation during the grain filling and ripening period of wheat in 2014 and 2015 are given in Table 1.

Table 1. Average air temperature and precipitation with calculations of temperature difference $(\Delta \mathrm{t})$ and precipitation $\%$ of long-term average

\begin{tabular}{|c|c|c|c|c|c|}
\hline Year & Month & $\begin{array}{l}{ }^{\circ} \mathrm{C} \\
\text { Air temperature }\end{array}$ & $\begin{array}{l}\Delta \mathrm{t} \\
{ }^{\circ} \mathrm{C}\end{array}$ & $\begin{array}{l}\text { Precipitation } \\
\mathrm{mm}\end{array}$ & $\begin{array}{l}\text { Precipitation } \% \text { of } \\
\text { long-term average }\end{array}$ \\
\hline \multirow[t]{3}{*}{$1981-2011$} & May & 15.8 & & 62.2 & \\
\hline & June & 18.7 & & 63.3 & \\
\hline & July & 20.7 & & 56.0 & \\
\hline \multirow[t]{3}{*}{2014} & May & 15.2 & -0.6 & 65.6 & 105.5 \\
\hline & June & 19.3 & 0.6 & 54.8 & 86.6 \\
\hline & July & 21.8 & 1.1 & 2.2 & 3.9 \\
\hline \multirow[t]{3}{*}{2015} & May & 15.1 & -0.8 & 57.6 & 92.6 \\
\hline & June & 19.9 & 1.2 & 52.5 & 82.5 \\
\hline & July & 23.6 & 2.9 & 64.1 & 114.5 \\
\hline
\end{tabular}

Winter spelt (Triticum spelta L.) and winter emmer (Triticum dicoccon Schrank) wheat cultivars were grown under the organic farming conditions without fertilization and chemical treatment within the crop rotation: common pea $\rightarrow$ spelt/emmer $\rightarrow$ spring barley. The experimental material comprised 5 winter pure spelt cultivars: 'Altgold', 'Rubiota', 'Ebners Rotkorn', 'Ostro' and 'Oberkulmer Rotkorn', and 4 winter emmer cultivars: 'Guardiaregia', 'Molise', 'Agnone' and 'Farvento', acquired from co-operating institutions Saatbau at Linz, Austria, South Bohemia University at České Budějovice, Czech Republic and University of Molise at Campobasso, Italy. Grain and flour qualitative traits were analysed during two consecutive (2014 and 2015) growing periods. After hand harvest, the spikes of ancient wheat were dehulled on a laboratory machine KMPP 300 (JK Machinery, Czech Republic). Indirect baking quality indicators were determined in whole grain meal in four replicates. Wheat samples were milled using a FQC 109 mill (Kapacitív KKT, Hungary). Wet gluten quantity (WGQ) and gluten index (GI) were analysed by a Glutomatic 2200 and Centrifuge 2015 (Perten Instruments, Sweden) according to the standard method ICC 155 (Determination of wet gluten quantity and quality (gluten index ac. to Perten) of whole wheat (Triticum aestivum L.) meal and flour. Falling number (FN) was determined on Falling number 1100 (Perten Instruments) according to AACC Method 56-81.03 (Determination of falling number). Zeleny index (ZI) was determined using a shaker SDZT4 (Santec, Slovakia) in accordance with the Standard Method ICC 116/1 (Determination of the sedimentation value (according to Zeleny) as an approximate measure of baking quality). Protein quantity (PQ) was calculated from the determination of total nitrogen $(\mathrm{N})$ using the Kjeltec 1002 System (Tecator AB, Sweden), based on N $\times 5.7$ in dry matter (DM).

The rheological properties of dough were evaluated in flour obtained by grain milling on Quadrumat Senior (Brabender, Germany). Farinograph-AT (Brabender, Germany) was used to determine the water absorption (WA) capacity of flour in percent, dough development time (DDT) in minutes, dough stability (DSt) in minutes and dough softening (DSo) after 12 minutes in farinograph units (FU).

Baking test was performed according to the standard method ICC 131 (Method for test baking of wheat flours) at the water level of farinograph absorption with some modifications. The baking formula was flour $(600 \mathrm{~g}$, $14 \%$ moisture basis), compressed yeast $(9.46 \mathrm{~g})$, salt (7.89 g) and sugar $(9.78 \mathrm{~g})$. Doughs were mixed for 3 min (spelt) 
or 2 min (emmer), left to rise for $30 \mathrm{~min}$ in a fermentation chamber UNOX XF 195 (Italy). The dough was punched, moulded, put into a baking pan and left for fermentation for another $90 \mathrm{~min}$ (spelt) or $70 \mathrm{~min}$ (emmer). Dough was baked for $20 \mathrm{~min}$ at $225^{\circ} \mathrm{C}$ temperature. Baking tests were performed in triplicate. Bread volume was determined $24 \mathrm{~h}$ after baking by the AACC Method 10-05.01 (Guidelines for measurement of volume by rapeseed displacement) using volumeter OBK (Mezos, Czech Republic), and specific bread volume (SBV) was calculated.

Dough mixing and pasting behaviour was analysed using the device Mixolab II (CHOPIN Technologies, France) according to the AACC Method 54-60.01 (Determination of rheological behaviour as a function of mixing and temperature increase in wheat flour and whole wheat meal by Mixolab). ChopinWheat + standard protocol settings were as follows: total analysis time $45 \mathrm{~min}$, dough weight 75 $\mathrm{g}$, hydration water temperature $30^{\circ} \mathrm{C}$. Maximum consistency of dough during the $1^{\text {st }}$ test phase was $1.10 \mathrm{Nm}( \pm 0.05 \mathrm{Nm})$; temperature regime: $8 \mathrm{~min}$ at $30^{\circ} \mathrm{C}$, heating at a rate of

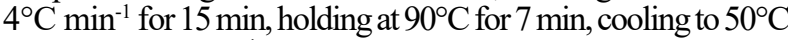
at a rate of $4^{\circ} \mathrm{C} \mathrm{min}-1$ for $10 \mathrm{~min}$, holding at $50^{\circ} \mathrm{C}$ for $5 \mathrm{~min}$.

Physical state of the tested dough during mixing and heating stage (Dubat, 2010) was reflected in measured quality parameters: torque $\mathrm{Cl}$, maximum torque during the $1^{\text {st }}$ mixing phase - initial mixing, objective target; torque $\mathrm{Cs}-$ in the $8^{\text {th }}$ minute of the Mixolab test; torque C2 (lowest point of the curve) - protein weakening, based on mechanical work and temperature increase, decrease in dough consistency; torque C3 (maximum torque during the heating stage) - the starch gelatinization; torque $\mathrm{C} 4$ (minimum torque during the heating stage) - the stability of the hot gel formed and amylolytic activity; torque C5 (torque after cooling at $50^{\circ} \mathrm{C}$ ) - starch retrogradation during the cooling stage; difference $\mathrm{C} 1-\mathrm{C} 2-$ the protein network strength under increasing heating stage; difference $\mathrm{Cs}-\mathrm{C} 2-$ protein quality; difference $\mathrm{C} 3-$
$\mathrm{C} 2$ - starch gelatinisation rate; difference $\mathrm{C} 3-\mathrm{C} 4-\alpha-$ amylase activity, linked to falling number; difference $\mathrm{C} 5$ $-\mathrm{C} 4$ - starch retrogradation at cooling stage, corresponds to the anti-stalling effects and represents the shelf life of the end product; slope $\alpha$ (the slope of the curve between $\mathrm{C} 1$ and $\mathrm{C} 2$ ) - the protein network weakening speed under heating effect; slope $\beta$ (the slope of the curve between $\mathrm{C} 2$ and C3) - starch gelatinization (pasting) speed; slope $\gamma$ (the slope of the curve between $\mathrm{C} 3$ and $\mathrm{C} 4$ ) - enzymatic $(\alpha$-amylase) degradation speed; difference T3 - T2 starch gelatinization time, in minutes.

Statistical analysis. The collected data were subjected to multifactorial analysis of variance (ANOVA). Significant differences between factors were determined by $F$-test at $p<0.05, p<0.01$ and $p<0.001$ probability levels; significantly different means were calculated by Fisher's least significant difference test at $p<0.05$. Pearson's correlation coefficients were calculated to evaluate the relationships between analysed parameters and considered significant at the level of $p<0.01$. The principal component analysis (PCA) was applied for reduction of the complexity of data sets to a small number of independent principal components for the assessment of the association between groups of variables and an understanding of the primary components, which contribute to the underlying variability of data set. The statistical analysis was performed with the software Statistica, version 10.0 (StatSoft Inc., USA) and $S A S E G$, version 5.1 (SAS, USA).

\section{Results and discussion}

Wheat grain and flour quality. The spelt wheat cultivars were characterized by significantly higher average quantity of protein $(15.8 \%$, range $15.0-16.6 \%)$ than emmer ones $(13.1 \%$, range $12.7-13.5 \%)$; significant differences were recorded among the growing years and the interaction between Triticum species and growing years (Table 2).

Table 2. Grain and flour quality parameters of emmer and spelt wheat

\begin{tabular}{|c|c|c|c|c|c|c|c|}
\hline \multirow{2}{*}{ Parameter } & \multicolumn{2}{|c|}{ Triticum dicoccon } & \multicolumn{2}{|c|}{ Triticum spelta } & \multirow[b]{2}{*}{$p_{1}$} & \multirow{2}{*}{$p_{2}$} & \multirow{2}{*}{$p_{3}$} \\
\hline & mean $\pm \mathrm{SD}$ & range & mean $\pm \mathrm{SD}$ & range & & & \\
\hline Protein quantity (PQ) \% & $13.13 \pm 1.51$ & $12.63-13.52$ & $15.81 \pm 1.83$ & $15.02-16.63$ & $* * *$ & $* * *$ & $* * *$ \\
\hline Wet gluten quantity (WGQ) \% & $5.3 \pm 8.0$ & $1.7-11.0$ & $41.4 \pm 6.3$ & $38.3-44.5$ & $* * *$ & $* * *$ & $* * *$ \\
\hline Zeleny index $(\mathrm{ZI}) \mathrm{ml}$ & $12.0 \pm 3.3$ & $11.3-12.7$ & $25.0 \pm 5.1$ & $20.7-30.3$ & $* * *$ & $* * *$ & $*$ \\
\hline Gluten index (GI) \% & $61.4 \pm 29.9$ & $38.4-76.8$ & $34.4 \pm 13.6$ & $21.9-51.6$ & $* * *$ & $* * *$ & $* * *$ \\
\hline Falling number (FN) s & $401 \pm 43$ & $363.2-428.3$ & $395.9 \pm 80.6$ & $338.5-508.4$ & ns & $* *$ & ns \\
\hline Water absorption (WA) $\%$ & $60.5 \pm 4.7$ & $59.0-61.5$ & $59.6 \pm 1.8$ & $57.7-61.5$ & $* *$ & $* * *$ & $* * *$ \\
\hline Dough development time (DDT) min & $0.91 \pm 0.61$ & $0.49-1.41$ & $2.11 \pm 0.81$ & $1.61-2.98$ & $* * *$ & $* * *$ & ns \\
\hline Dough stability (DSt) min & $1.46 \pm 0.79$ & $0.57-2.05$ & $3.23 \pm 1.82$ & $2.13-5.28$ & $* * *$ & $* * *$ & $* * *$ \\
\hline Dough softening (DSo) FU & $144.6 \pm 35.4$ & $119.0-190.6$ & $95.4 \pm 37.4$ & $81.5-122.1$ & $* * *$ & $* * *$ & ns \\
\hline Specific bread volume (SBV) $\mathrm{cm}^{3} \mathrm{~kg}^{-1}$ & $3286 \pm 199$ & $3004-3436$ & $3861 \pm 254$ & $3741-4187$ & $* * *$ & ns & ns \\
\hline
\end{tabular}

Note. Source of variation: $p_{1}$ - Triticum species, $p_{2}$ - growing years, $p_{3}$ - species and growing years interaction; SD - standard deviation level of significance of treatment factors determined by the $F$-test at $* p<0.05$, ** $p<0.01$ and $* * * p<0.001$; ns - not significant.

Flours suitable for bread making are those with high protein quantity (PQ) in the range from $11-14 \%$. Therefore, PQ is one of the most important criteria in determination of wheat quality. Higher amount of good quality protein is required for gas retention and dough rise during fermentation or early stages of bread baking (Papouškova et al., 2011). For spelt wheat cultivars, similar data of PQ were reported by Bernas et al. (2016) and lower values - by Wiwart et al. (2017). For spelt wheat cultivars, PQ was significantly correlated with wet gluten quantity (WGQ) $(r=0.94)$, water absorption (WA) $(r=0.73)$, dough development time (DDT) $(r=0.83)$ and Zeleny index (ZI) $(r=0.66)$; for emmer wheat cultivars, strong but negative correlation of $\mathrm{PQ}$ with gluten index (GI) $(r=-0.81)$ was determined (Table 3). Similar correlation $\left(r^{2}=0.62\right)$ between PQ and SDS (sodium dodecyl sulphate) sedimentation value was reported for common wheat by Dhaka et al. (2012).
Zeleny index (ZI) is a useful, small-scale test, widely accepted for wheat samples discrimination on wet gluten quantity and quality. ZI below $25 \mathrm{ml}$ is generally regarded as less suitable for baking. In our experiment, ZI values for spelt were determined in the range of 20.7-30.3 ml (from weak to improving flour), while emmer exhibited low values - from 11.3-12.7 ml. ZI was significantly affected by Triticum species, growing years and their interaction. According to Majewska et al. (2007) and Bernas et al. (2016), lower values of ZI (11.0-27.0 ml) are typical for spelt, but for emmer sedimentation value (ZI) ranged from 11.5 to $17.0 \mathrm{ml}$ (Mondini et al., 2014); Wiwart et al. (2017) reported similar values $(20.0-35.0 \mathrm{ml})$ for spelt wheat cultivars. ZI positively correlated with water absorption (strong correlation coefficient for both species $r=0.78$ and $r=0.83$ ) and dough development time (medium strong correlation coefficient for spelt).

The falling number (FN) of all analysed samples of spelt ranged from 338 to $508 \mathrm{~s}$, and of the samples 
Table 3. Correlation coefficients between grain, rheological and bread quality parameters of spelt and emmer (bold) wheat

\begin{tabular}{|c|c|c|c|c|c|c|c|c|c|c|c|c|c|c|c|}
\hline & $\mathrm{C} 4$ & C5 & $\alpha$ & $\beta$ & $\gamma$ & WA & DDT & DSt & DSo & ZI & FN & WGQ & GI & SBV & PQ \\
\hline $\mathrm{C} 2$ & & & -0.91 & & & & & 0.69 & $\begin{array}{l}-0.59 \\
-\mathbf{0 . 8 5}\end{array}$ & -0.72 & & 0.65 & 0.51 & 0.80 & \\
\hline $\mathrm{C} 3$ & $\begin{array}{l}0.63 \\
0.95\end{array}$ & $\begin{array}{l}0.79 \\
\mathbf{0 . 9 1}\end{array}$ & & & 0.77 & -0.95 & -0.77 & $\begin{array}{c}0.62 \\
-0.68\end{array}$ & -0.46 & $\begin{array}{l}-0.50 \\
-\mathbf{0 . 8 1}\end{array}$ & 0.62 & & & -0.47 & -0.64 \\
\hline $\mathrm{C} 4$ & & $\begin{array}{l}0.68 \\
\mathbf{0 . 9 8}\end{array}$ & & -0.66 & 0.91 & -0.86 & -0.68 & -0.62 & -0.56 & -0.70 & 0.81 & & -0.65 & & \\
\hline $\mathrm{C} 5$ & & & 0.59 & $\begin{array}{r}0.64 \\
-0.77\end{array}$ & 0.93 & $\begin{array}{l}-0.47 \\
-0.79\end{array}$ & & & & $\begin{array}{l}-0.64 \\
-0.69\end{array}$ & $\begin{array}{l}0.60 \\
0.86\end{array}$ & & -0.66 & -0.63 & -0.55 \\
\hline$\alpha$ & & & & 0.63 & & & & & 0.74 & $\begin{array}{c}-0.52 \\
\mathbf{0 . 8 2}\end{array}$ & 0.53 & & & -0.71 & \\
\hline$\beta$ & & & & & -0.74 & & & & & & $\begin{array}{c}0.52 \\
-\mathbf{0 . 8 7}\end{array}$ & & & & -0.65 \\
\hline$\gamma$ & & & & & & -0.70 & & & & -0.65 & $\begin{array}{l}0.63 \\
\mathbf{0 . 8 3}\end{array}$ & 0.59 & 0.58 & & \\
\hline WA & & & & & & & $\begin{array}{l}0.86 \\
\mathbf{0 . 7 9}\end{array}$ & 0.64 & & $\begin{array}{l}0.78 \\
\mathbf{0 . 8 3}\end{array}$ & & 0.65 & 0.48 & & 0.73 \\
\hline DDT & & & & & & & & 0.97 & -0.67 & 0.68 & & 0.85 & 0.48 & 0.69 & 0.83 \\
\hline DSt & & & & & & & & & $\begin{array}{l}-0.88 \\
-\mathbf{0 . 7 9}\end{array}$ & & & & 0.69 & 0.82 & \\
\hline DSo & & & & & & & & & & & & & -0.75 & -0.87 & \\
\hline ZI & & & & & & & & & & & & 0.59 & & 0.75 & 0.66 \\
\hline $\mathrm{FN}$ & & & & & & & & & & & & & $\begin{array}{r}0.57 \\
-0.82\end{array}$ & & 0.78 \\
\hline $\begin{array}{c}\text { WGQ } \\
\text { GI }\end{array}$ & & & & & & & & & & & & & & 0.71 & $\begin{array}{c}0.94 \\
-\mathbf{0 . 8 1} \\
\end{array}$ \\
\hline
\end{tabular}

Note. Only the correlations significant at $p<0.01$ are shown; $\mathrm{C} 2$ - protein weakening, $\mathrm{C} 3$ - starch gelatinization, $\mathrm{C} 4$ - amylolytic activity, C5 - starch retrogradation, slope $\alpha$ - protein network weakening speed, slope $\beta$-starch gelatinization speed, slope $\gamma$ - enzymatic degradation speed, WA - water absorption, DDT - dough development time, DSt - dough stability, DSo - dough softening, ZI - Zeleny index, FN - falling number, WGQ - wet gluten quantity, GI - gluten index, SBV - specific bread volume, PQ - protein quantity.

of emmer - from 363 to 428 s. The differences between species were not significant. Significant differences were noticed in respect to growing years, but in all experimental years, FN was higher than $330 \mathrm{~s}$, which indicates low $\alpha$ amylase activity of grain. FN around $250 \mathrm{~s}$ is considered to be ideal for baking (Wiwart et al., 2017).

The gluten proteins are responsible for unique bread making properties of wheat. On average, wet gluten quantity (WGQ) of spelt was significantly higher $(41.4 \%$, range $38.3-44.5 \%)$ than emmer $(5.3 \%$, range $1.7-11.0 \%)$; significant influence of species, environmental conditions and their interaction were recorded. WGQ was a parameter with the highest variation throughout the entire experiment for emmer (coefficient of variation $=151.7 \%$ ); the variation for spelt was lower $(15.2 \%)$. Values of WGQ higher than $10 \%$ were achieved in the growing period with very warm and dry weather during grain filling and ripening (May, June and July). In contrast to our results, in the set of different cultivars and environments, Tran et al. (2020) reported higher values of WGQ for emmer (37.9\%) but with low gluten index $(15.4 \%)$. Wet gluten is probably a trait with very high variability depending on the emmer wheat cultivar, environment and their interaction. Therefore, the selection of cultivar for particular environment is crucial for achieving targeted yield and quality parameters.

Gluten index (GI) is related to the strength and elasticity of gluten: lower values than 65 indicate that flour is weak for bread production, higher values than 80 mean that gluten is strong (Migliorini et al., 2016). Highly significant differences were noticed in Triticum species, growing years and their interaction, lower gluten index was observed in spelt (34.4\%, range 21.9-51.6\%). Emmer exhibited higher gluten index (61.4\%, range 38.9-76.8\%), which indicated gluten quality from weak to medium strong. Gluten index negatively correlated $(r=-0.75)$ with parameter dough softening (DSo) and positively correlated $(r=0.68)$ with dough stability (DSt) for spelt; these results were not confirmed for emmer. Wiwart et al. (2017) reported that the quality of dough made from spelt flour was not correlated with wet gluten quantity but was correlated with gluten index, and dough stability was also influenced by gluten quality, not quantity.

Rheological properties of dough. Rheological properties such as water absorption, dough development time, dough stability and dough softening varied significantly between the Triticum species with high influence of environmental conditions. As an indicator of baking quality, water absorption significantly differed between the species but was high for both of them and ranged from $57.7 \%$ to $61.5 \%$. The lowest water absorption for emmer (63.5\%) was reported by Rachon et al. (2016) with significant effect of weather condition, when substantial rainfall caused lowering of wet gluten quantity together with water absorption. Strong wheat is characterised by longer dough development time ( $\geq 3 \mathrm{~min})$, dough stability ( $\geq 4 \mathrm{~min}$ ) and lower dough softening ( $\leq 40 \mathrm{FU})$. Emmer was characterised by significantly shorter dough development time (0.91 min, range $0.49-1.41 \mathrm{~min}$ ) than spelt $(2.11 \mathrm{~min}$, range $1.61-2.98 \mathrm{~min})$, shorter dough stability (1.46 $\mathrm{min}$, range $0.57-2.05 \mathrm{~min}$ ) compared to spelt (3.23 $\mathrm{min}$, range $2.13-5.28 \mathrm{~min}$ ) and significantly higher dough softening. The differences between the species in quality parameters were reflected in the correlations of these characters. Strong correlations between water absorption and dough development time were determined for both species. In the case of spelt, water absorption and dough development time highly correlated also with protein quantity.

The Mixolab process has the advantage of being able to measure properties of proteins, starch and associated enzymes in one test. The Mixolab results are summarised in Table 4, and examples of Mixolab curves - in Figure 1.

The parameters $\mathrm{C} 2$ (protein weakening), difference $\mathrm{C} 1-\mathrm{C} 2$ (protein network strength) and slope $\alpha$ (protein network weakening speed) were recorded when heating reached $52-57^{\circ} \mathrm{C}$ temperature during the $2^{\text {nd }}$ phase. $\mathrm{C} 2$ and $\mathrm{C} 1-\mathrm{C} 2$ values were not affected by the Triticum species. Higher values of $\mathrm{C} 1-\mathrm{C} 2$ are indicative of lower level of proteolytic activity (Švec, Hrušková, 2015). The mean of C2 values for both species were below $0.4 \mathrm{Nm}(0.29$ and $0.32 \mathrm{Nm})$ and indicated that dough will be less tolerant to mixing. Good quality 
Table 4. Mixolab parameters related to emmer and spelt wheat protein and starch characteristics

\begin{tabular}{|c|c|c|c|c|c|c|c|}
\hline \multirow{2}{*}{ Parameter } & \multicolumn{2}{|c|}{ Triticum dicoccon } & \multicolumn{2}{|c|}{ Triticum spelta } & \multirow[b]{2}{*}{$p_{1}$} & \multirow{2}{*}{$p_{2}$} & \multirow{2}{*}{$p_{3}$} \\
\hline & mean $\pm \mathrm{SD}$ & range & mean $\pm \mathrm{SD}$ & range & & & \\
\hline $\mathrm{C} 2$ (protein weakening) $\mathrm{Nm}$ & $0.29 \pm 0.06$ & $0.23-0.33$ & $0.32 \pm 0.07$ & $0.27-0.39$ & ns & ** & ns \\
\hline Slope $\alpha$ (protein network weakening speed) Nm min ${ }^{-1}$ & $-0.05 \pm 0.01$ & $-0.04--0.05$ & $-0.07 \pm 0.03$ & $-0.04--0.11$ & $* *$ & ns & ns \\
\hline $\mathrm{C} 1-\mathrm{C} 2$ (protein network strength) $\mathrm{Nm}$ & $0.80 \pm 0.06$ & $0.75-0.85$ & $0.78 \pm 0.07$ & $0.75-0.82$ & ns & ** & ns \\
\hline Cs (torque in the $8^{\text {th }}$ min of the Mixolab test) Nm & $0.64 \pm 0.10$ & $0.53-0.71$ & $0.87 \pm 0.13$ & $0.73-0.96$ & $* * *$ & $*$ & ns \\
\hline $\mathrm{Cs}-\mathrm{C} 2$ (protein quality) $\mathrm{Nm}$ & $0.35 \pm 0.05$ & $0.30-0.39$ & $0.54 \pm 0.08$ & $0.46-0.60$ & $* * *$ & ns & * \\
\hline $\mathrm{C} 3$ (starch gelatinization) $\mathrm{Nm}$ & $1.61 \pm 0.19$ & $1.45-1.69$ & $1.67 \pm 0.15$ & $1.61-1.80$ & ns & $* * *$ & ns \\
\hline $\mathrm{C} 4$ (amylolytic activity) $\mathrm{Nm}$ & $1.34 \pm 0.34$ & $0.98-1.55$ & $1.40 \pm 0.20$ & $1.31-1.51$ & ns & $* * *$ & ns \\
\hline $\mathrm{C} 3-\mathrm{C} 4$ ( $\alpha$-amylase activity) $\mathrm{Nm}$ & $0.26 \pm 0.17$ & $0.14-0.47$ & $0.27 \pm 0.16$ & $0.15-0.32$ & ns & ns & ns \\
\hline C5 (starch retrogradation) $\mathrm{Nm}$ & $1.98 \pm 0.58$ & $1.400-2.30$ & $2.45 \pm 0.59$ & $1.97-2.96$ & $* *$ & $* * *$ & ns \\
\hline Slope $\beta$ (starch gelatinization speed) $\mathrm{Nm} \mathrm{min}{ }^{-1}$ & $0.41 \pm 0.08$ & $0.36-0.47$ & $0.63 \pm 0.13$ & $0.47-0.71$ & $* * *$ & ns & ns \\
\hline Slope $\gamma$ (enzymatic degradation speed) $\mathrm{Nm} \mathrm{min}^{-1}$ & $-0.04 \pm 0.03$ & $-0.02--0.07$ & $-0.03 \pm 0.01$ & $-0.0--0.05$ & ns & ns & * \\
\hline $\mathrm{T} 3-\mathrm{T} 2$ (starch gelatinization time) $\mathrm{min}$ & $7.54 \pm 1.68$ & $6.34-8.33$ & $6.21 \pm 1.11$ & $5.46-7.82$ & $* *$ & $*$ & $* *$ \\
\hline
\end{tabular}

Note. SD - standard deviation; source of variation: $p_{1}$ - Triticum species, $p_{2}$ - growing years, $p_{3}-$ species and growing years interaction; level of significance of treatment factors determined by the $F$-test at $* p<0.05,{ }^{* *} p<0.01$ and $* * * p<0.001$; ns - not significant.

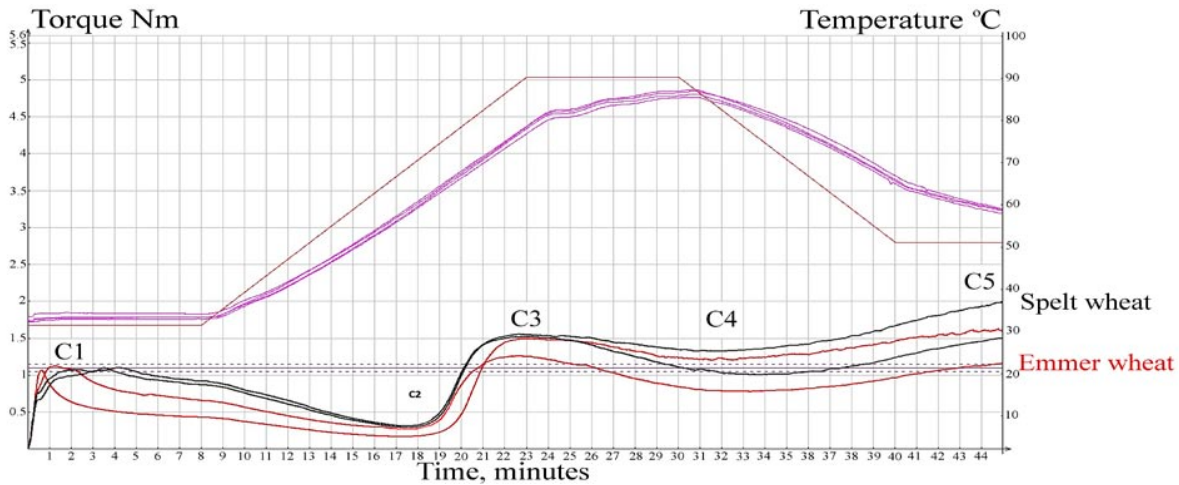

Figure 1. Examples of Mixolab curves of spelt and emmer wheat

proteins are represented by $\mathrm{C} 2-0.5-0.6 \mathrm{Nm}$ (Dhaka et al., 2012). During the $2^{\text {nd }}$ phase, starch started to gelatinize, the structures of proteins changed due to denaturation, starch granules (mainly damaged) started to swell, and these changes modified dough consistency (Jirsa et al., 2007). The greater the decrease in consistency, the lower the protein quality $(\mathrm{Cs}-\mathrm{C} 2)$.

Slope $\alpha$ (protein network weakening speed) was significant for both species with lower values for emmer $\left(-0.05 \mathrm{Nm} \mathrm{min}^{-1}\right)$ than for spelt $\left(-0.07 \mathrm{Nm} \mathrm{min}^{-1}\right)$, which confirmed lower protein quality of spelt. In the study of Wiwart et al. (2017), spelt with higher gluten index were characterized by lower slope $\alpha$, which was confirmed also in our experiment; but for emmer, Szafrańska (2010) for commercial wheat flour determined wide range of slope $\alpha$ (from -0.130 to $-0.006 \mathrm{Nm} \mathrm{min}^{-1}$ ) and suggested that slope $\alpha$ is probably not species-specific parameter. This opinion was not confirmed in our experiment for hulled wheat species.

In the present study, parameters Cs (torque in the $8^{\text {th }}$ minute of the Mixolab test) and the Cs $-\mathrm{C} 2$ (protein quality) were determined. In both parameters, significant differences between the Triticum species with lower values and higher protein quality for emmer were found. Negative correlations for both species were noticed between parameters $\mathrm{C} 2$ (protein weakening) and DSo (dough softening) $(r=-0.59$ for spelt and $r=-0.85$ for emmer), which was expected. Moreover, protein weakening correlated with dough stability (DSt) and gluten index (GI) in the case of spelt, and protein weakening with Zeleny index (negative) and wet gluten quantity (WGQ) for emmer.

During the $3^{\text {rd }}$ phase of Mixolab curve, the evaluated parameters were torque $\mathrm{C} 3$ (starch gelatinization) and slope $\beta$ (starch gelatinization speed): the heating continued, dough remained under constant mixing, protein denaturation and starch gelatinization were stopped. Maximum torque during the heating stage starch gelatinization did not statistically differ between both species and averaged 1.61 and $1.67 \mathrm{Nm}$. The parameter slope $\beta$ was significant for the Triticum species; lower slope $\beta$ and slower starch gelatinization process was determined for emmer $-0.41 \mathrm{Nm} \mathrm{min}^{-1}$, for spelt $-0.63 \mathrm{Nm} \mathrm{min}^{-1}$. Significantly longer starch gelatinization time $(\mathrm{T} 3-\mathrm{T} 2)$ had emmer (7.54 min) than spelt (6.34 min).

Although studies on the Mixolab characteristics of hulled wheat species are scarce, for spelt and emmer, lower parameter torque C3 (starch gelatinization) (1.54 and $1.22 \mathrm{Nm}$ ) and shorter parameter T3 - T2 (starch gelatinization time) (5.0 and $5.2 \mathrm{~min})$ were reported by Rachoń et al. (2016). Wiwart et al. (2017) observed positive correlation between parameters slope $\beta$ and FN (falling number) for spelt, which provides information about the hydrolytic activity of $\alpha$-amylase during heating. This correlation (medium) was confirmed also in our experiment for spelt. In the case of emmer, strong negative correlation between slope $\beta$ and FN was found $(r=-0.87)$.

During the $4^{\text {th }}$ phase, the enzymatic activity and heat stability of the starch gel at the temperature above $80^{\circ} \mathrm{C}$ were evaluated. The parameters torque $\mathrm{C} 4$ (amylolytic activity), difference C3 - C4 ( $\alpha$-amylase activity) and slope $\gamma$ (enzymatic degradation speed) were assessed. None of these parameters was significantly influenced by the analysed Triticum species; significant differences were observed between growing years.

During the $5^{\text {th }}$ phase, when the dough was cooled to $50^{\circ} \mathrm{C}$ temperature, the parameter $\mathrm{C} 5$ (starch 
retrogradation) was evaluated. Significantly higher value of starch retrogradation was recorded for spelt $(2.45 \mathrm{Nm})$, probably due to the higher starch gelatinization speed during the heating stage. The parameters of Mixolab related to starch characteristics correlated with FN (positively) and ZI (negatively). For spelt, medium strong correlations were determined between parameters $\mathrm{C} 5$, slope $\beta$ and $\mathrm{FN}$; for emmer, correlations of parameters $\mathrm{C} 4$ and $\mathrm{C} 5$, slope $\gamma$, FN were strong. Unlike in our experiment, no significant correlations were found between $\mathrm{FN}$ and torques $\mathrm{C} 3, \mathrm{C} 4$ and C5 for spelt (Szafrańska et al., 2015).

Bread quality. Triticum species used in this experiment varied in flour and rheological characteristics; therefore, bread produced was significantly different in the specific bread volume (SBV). Higher SBV yielded spelt $\left(3861.0 \mathrm{~cm}^{3} \mathrm{~kg}^{-1}\right)$ compared to emmer $\left(3286.0 \mathrm{~cm}^{3} \mathrm{~kg}^{-1}\right)$; the effect of climatic conditions was not significant. Correlations were determined between spelt flour and dough quality parameters and direct bread quality. The SBV had the highest correlation with ZI $(r=0.75)$, negative with parameters slope $\alpha$ (protein network weakening speed) $(r=-0.71)$ and C5 (starch retrogradation) $(r=-0.63)$.

Results showed that torque $\mathrm{C} 2$ (protein weakening) did not correlate with SBV, probably due to the high slope $\alpha$ (protein network weakening speed) and lower $\mathrm{C} 1-\mathrm{C} 2$ (protein network strength). In the case of emmer, strong positive correlations between parameters SBV and C2 $(r=0.80)$, DSt $(r=0.82)$ and WGQ (wet gluten quantity) $(r=0.71)$ were determined. In the study of Dhaka et al. (2012), these differences were attributed to glutenin and gliadin ratio, which highly correlated with SBV and rheological parameters: dough development time (DDT), dough stability (DSt), gluten index (GI) and protein weakening $(\mathrm{C} 2)$. In our experiment, the most suitable parameters for prediction of spelt bread making quality and higher SBV were ZI and slope $\alpha$. For emmer, the potential of C2 and WGQ was confirmed for SBV prediction. The parameter PQ (protein quantity) did not correlate with SBV for the studied cultivars of emmer and spelt wheat.

Principal component analysis (PCA). The relationships among the commonly used quality and rheological parameters and characteristics tested by Mixolab for the Triticum species were evaluated by PCA. The results of PCA revealed that the analysed Triticum species were strongly discriminated by the grain quality (ZI and FN), rheological quality (DSt and DSo), Mixolab parameters $\mathrm{C} 2, \mathrm{C} 3, \mathrm{C} 4, \mathrm{C} 5, \mathrm{C} 1-\mathrm{C} 2$ and $\mathrm{SBV}$.

In Figure 2, PCA of spelt wheat quality characteristics including 11 quality parameters showed that $83 \%$ of the variability can be explained by the three principal components (PC) selected according to the Kaiser's principle (Stankovičová, Vojtková, 2007).
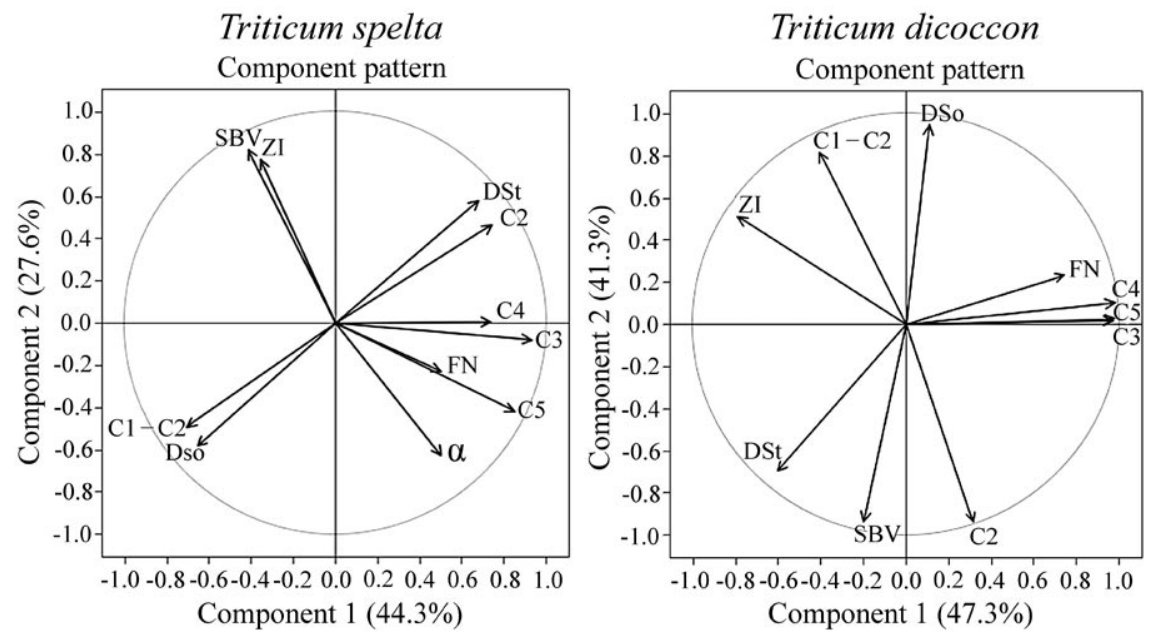

Parameters: DSt - dough stability, DSo - dough softening, FN - falling number, SBV - specific bread volume, slope $\alpha$ - protein network weakening speed, torques C2 - protein weakening, C3 - starch gelatinization, C4 - amylolytic activity, C5 - starch retrogradation, $\mathrm{C} 1-\mathrm{C} 2$ - protein network strength, ZI - Zeleny index

Figure 2. Pattern component plots presenting principal component analysis (PCA) for spelt and emmer wheat

Accounting for $44.3 \%$ of the variability, the $\mathrm{PC} 1$ was positively related to the parameters $\mathrm{C} 3, \mathrm{C} 4$, $\mathrm{C} 5$ and $\mathrm{C} 2$ and negatively related mainly to $\mathrm{C} 1-\mathrm{C} 2$. The PC2, representing $27.6 \%$ of the variability, was positively influenced by parameters ZI and SBV with equal contribution to $\mathrm{PC} 2$ and negatively influenced mainly by slope $\alpha$. The PC3 with $11.1 \%$ of variability was mainly related to parameter FN (data not shown). These results are consistent with the highly significant correlations between baking parameters SBV and ZI and negative correlation between SBV and slope $\alpha$.

In the case of emmer, PCA showed that $88.5 \%$ of the variability could be explained by the first two principal components. $\mathrm{PC} 1$, representing $47.3 \%$ of the variability, was positively related to the parameters $\mathrm{C} 3$, $\mathrm{C} 4$ and C5. Parameter FN also contributed to the PC1, but its effect was lower. The PC2, accounted for $41.3 \%$ of the variability, was positively related to parameters DSo, $\mathrm{C} 1-\mathrm{C} 2$ and negatively related to Mixolab parameter C2 and baking parameter SBV. The results are supported by significant correlations between parameters SBV and C2, SBV and DSo.

It is difficult to directly compare the results obtained in our experiment with those achieved in other research that represented different Triticum species, cultivars, climate conditions, growing technologies, etc. Several factors such as Mixolab parameters protein weakening (C2), protein network weakening speed (slope $\alpha$ ), dough stability (DSt), dough development time (DDT), protein quantity (PQ), gluten index (GI) and sedimentation value (ZI) are predominantly linked to specific bread volume (SBV). Dhaka et al. (2012) reported that Mixolab parameters dough stability and protein weakening had the potential to predict the bread making quality of common wheat cultivars.

Results of our experiment showed, that in the case of spelt, ZI had the potential to predict direct bread making quality parameter SBV. For emmer, Mixolab 
parameter C2 and farinograph DSt can be related to direct bread making quality.

\section{Conclusions}

The examined ancient spelt (Triticum spelta L.) and emmer (Triticum dicoccon Schrank) wheat species differed considerably in indirect grain quality, rheological and direct baking quality indicators.

1. Higher protein quantity and Zeleny index $(\mathrm{ZI})$ were determined for spelt $(15.8 \%, 25.0 \mathrm{ml})$ compared to emmer $(13.1 \%, 12.0 \mathrm{ml})$.

2. Wet gluten quantity (WGQ) was much higher for spelt $(41.4 \%)$ than that for emmer $(5.3 \%)$, but quality of gluten expressed as gluten index was higher for emmer $(61.4 \%)$ than for spelt $(34.4 \%)$.

3. Spelt was characterised by a longer farinograph dough development time (DDT), dough stability (DSt), whereas water absorption (WA) was high for both wheat species.

4. A clear distinction between Triticum species was found in Mixolab parameters related to protein characteristics: protein network weakening speed (slope $\alpha$ ), torque in the $8^{\text {th }}$ minute of the Mixolab test $(\mathrm{Cs})$, protein quality $(\mathrm{Cs}-\mathrm{C} 2)$, and to starch characteristics: starch gelatinization speed (slope $\beta$ ) and starch retrogradation (torque C5). Specific bread volume (SBV) was higher for spelt compared to emmer wheat cultivars.

5. For emmer, parameters WGQ, DSt, DDT and torque $\mathrm{C} 2$ (protein weakening) were found to be highly associated with SBV.

6. SBV of spelt was highly and positively correlated with ZI and negatively correlated with slope $\alpha$, showing the potential of these parameters for SBV prediction. In this experiment, Mixolab pasting properties of spelt as starch gelatinisation (torque C3) and starch retrogradation (torque $\mathrm{C5}$ ) had medium relationship with direct baking quality. SBV of emmer did not correlate with Mixolab parameters related to starch characteristics.

\section{Acknowledgements}

This research was financially supported by the Ministry of Education, Science, Research and Sport of the Slovak Republic, project VEGA No. 1/0218/20 (75\%) and the Operational Program Integrated Infrastructure within the project: SMARTFARM 313011W112, cofinanced by the ERDF (25\%).

Received 28122020

Accepted 29042021

\section{References}

Abdel-Samie M. A. S., Wan J., Huang W., Chung O., Xu B. 2010 Effect of cumin and ginger on dough mixing properties and conkie quality. Cereal Chemistry, 87 (5): 454-460. https://doi.org/10.1094/CCHEM-01-10'-0012

Arzani A., Ashraf M. 2017. Cultivated ancient wheats (Triticum spp.): a potential source of health-beneficial food products. Comprehensive Reviews in Fond Science and Fond Safety, 16 (3): 477-488. https://doi.org/10.1111/1541-4337.12262

Barański M., Lacko-Bartošová M., Rembiałkowska E., LackoBartošová L. 2020. The effect of species and cultivation year on phenolic acids content in ancient wheat A gronomy, 10 (5): 673. https://doi.org/10.3390/agronomy 10050673

Bernas J., Konvalina P., Moudry J. Jr., Vlasek O., Jelinkova Z. 2016. Technological quality of spelt wheat and environmental impact of spelt wheat growing. International Journal of Advances in Science Engineering and Technology, 4 (3): 128-131.

Cooper R. 2015. Re-discovering ancient wheat varieties as functional foods. Journal of Traditional and Complementary Medicine 5(3) $138-143$

https://doi.org/10.1016/j.jtcme.2015.02.004
Dhaka V., Gulia N., Khatkar B. S. 2012. Application of Mixolab to assess the bread making quality of wheat varieties. Open Access Scientific Reports. 1: 183. https://doi.org/10.4172/scientificreports. 183

Dinu M., Whittaker A., Pagliai G., Benedettelli S., Sofi F. 2018. Ancient wheat species and human health: biochemical and clinical implications. Journal of Nutritional Biochemistry, 52: 1-9. https://doi.org/10.1016/j.jnutbio.2017.09.001

Dubat A. 2010. A new AACC International approved method to measure rheological properties of a dough sample. Cereal Foods World. 55 (3): 150-153. https://doi.org/10.1094/CFW-55-3-0150

Jirsa O., Hrušková M., Svec I. 2007. Bread features evaluation by NIR analysis. Czech Journal of Food Sciences, 25 (5): 243-248. https://doi.org/10.17221/683-CJFS

Kahraman K., Sakiyan O., Ozturk S., Koksel H., Sumnu G., Dubat A. 2008. Utilization of Mixolab to predict the suitability of flours in terms of cake quality. European Food Research and Technology. 227 (2): 565-570. https://doi.org/10.1007/s00217-007-0757-y

Koksel H., Kahraman K., Sanal T., Ozay D. S., Dubat A. 2009. Potential utilization of Mixolab for quality evaluation of bread wheat genotypes. Cereal Chemistry. 86 (5): 522-526. https://doi.org/10.1094/CCHEM-86-5-0522

Majewska K., Dąbrowska E., Zuk-Gołaszewska K., Tyburski J. 2007. Baking quality of flour obtained from grain of chosen spelt varieties (Triticum spelta L.). Zywność Nauka Technologia Jakość, 2 (51): 60-71 (in Polish).

Markowski M., Žuk-Gołaszewska K., Kwiaktowski D. 2013. Influence of variety on selected physical and mechanical properties of wheat. Industrial Crops and Products. 47: 113-117. https://doi.org/10.1016/j.indcrop.2013.02.024

Migliorini P., Spagnolo S., Torri L., Arnoulet M., Lazzerini G., Eccarelli S. 2016. Agronomic and quality characteristics of old, modern and mixture wheat varieties and landraces for organic bread chain in diverse environments of northern Italv. European Journal of Agronomv. 79: 131-141. https://doi.org/10.1016/j.eja.2016.05.011

Mondini L., Grausgruber H., Pagnotta M. A. 2014. Evaluation of European emmer wheat germplasm for agromorphological, grain quality traits and molecular traits. Genetic Resources and Crop Evaluation. 61 (1): 69-87. https://doi.org/10.1007/s10722-013-0016-y

Ozturk S., Kahraman K., Tiftik B., Koksel H. 2008. Predicting the cookie quality of flours by using Mixolab. European Food Research and Technology, 227 (5): 1549-1554. https://doi.org/10.1007/s00217-008-0879-x

Papouškova L., Capouchová I., Kostelanská M., Škeříková A., Prokinová E., Hajšlová J., Salava J., Faměra O. 2011. Changes in baking quality of winter wheat with different intensity of Fusarium spp. contamination detected by means of new rheological system Mixolab. Czech Journal of Food Sciences. 29 (4): 420-429. https://doi.org/10.17221/426/2010-CJFS

Rachoń L., Szumilo G., Szafrańska A., Kotyrba D. 2016. Bread-making potential of selected spring wheat species depending on crop year and production technology intensity. Zemdirbvste-Agriculture. 103 (4): 369-376. https://doi.org/10.13080/z-a.2016.103.047

Schmiele M., Ferrari Felisberto M. H., Clerici M. T. P. S., Chang Y. K. 2017. Mixolab for rheological evaluation of wheat flour partially replaced by soy protein hydrolysate and fructooligosacharides for bread production. LWT - Food Science and Technology. 76 (B): 259-269. https://doi.org/10.1016/j.lwt.2016.07.01

Shewry P. R. 2018. Do ancient types of wheat have health benefits compared with modern bread wheat? Journal of Cereal Science, 79: 469-476. https://doi.org/10.1016/j.jcs.2017.11.010

Shewry P. R., Hey S. 2015. Do "ancient" wheat species differ from modern bread wheat in their contents of bioactive components? Journal of Cereal Science, 65: 236-243. https://doi.org/10.1016/j.jcs.2015.07.014 
Stankovičová I., Vojtková M. 2007. Viacrozmerné štatistické metódy s aplikáciami [Multidimensional statistical methods with applications]. Bratislava, Slovenská Republika, $261 \mathrm{~s}$. (in Slovak).

Szafrańska A. 2010. Prediction of the quality of white flour based on results obtained by Mixolab for wholemeal flour. Prace Instytutow i Laboratoriow Badawczych Przemyslu Spozywczego, 65: 107-116 (in Polish).

Szafrańska A., Rachoń I., Szumilo G. 2015. Estimation of protein-starch complex of selected wheat species depending on production technology intensity. Zeszyty Problemowe Postępów Nauk Rolniczych, 582: 81-90.

Švec I., Hrušková M. 2015. The Mixolab parameters of composite wheat/hemp flour and their relation to quality features. LWT - Food Science and Technology. 60 (1): 623-629. https://doi.org/10.1016/j.lwt.2014.07.034

Švec I., Hrušková M. 2018. Effect of golden and brown linseed fibre on wheat flour pasting, dough properties and bread quality. Cereal Research Communications. 46 (1): 114 123. https://doi.org/10.1556/0806.45.2017.063
Tran K. D., Konvalina P., Capouchová I., Janovská D., LackoBartošová M., Kopecký M., Tran P. X. T 2020. Comparative study on protein quality and rheological behaviour of different wheat species. Agronomy. 10 (11): 1763. https://doi.org/10.3390/agronomy10111763

Wiwart M., Szafrańska A., Wachowska U., Suchowilska E. 2017. Quality parameters and rheological dough properties of 15 spelt (Triticum spelta L.) varieties cultivated today. Cereal Chemistry, 94 (6): 1037-1044. https://doi.org/10.1094/CCHEM-05-17-0097-R

Wolfe M. S., Baresel J. P., Desclaux D., Goldringer I., Hoad S., Kovacs G., Löschenberger F. Miedaner T., Ostergård H., Lammerts van Bueren E. T. 2008. Developments in breeding cereals for organic agriculture. Euphytica, 163 (3): 323-346. https://doi.org/10.1007/s10681-008-9690-9

Żuk-Gołaszewska K., Majewska K., Tyburski J., Golaszewski J. 2018. Physical and technological properties of kernels and flour made from spelt grown in an organic farming system in north-eastern Poland. Journal of Cereal Science, 79: 501-507. https://doi.org/10.1016/j.jcs.2018.01.002

\title{
Ekologiškų speltos ir dvigrūdžių kviečių tešlos reologinès savybès lemia duonos kokybę
}

\author{
M. Lacko-Bartošová ${ }^{1}$, L. Lacko-Bartošová1, P. Konvalina ${ }^{2}$, E. Matejková ${ }^{3}$, D. Bieliková ${ }^{1}$ \\ ${ }^{1}$ Slovakijos žemės ūkio universiteto Nitroje Agrobiologijos ir maisto išteklių fakultetas \\ ${ }^{2}$ Pietų Bohemijos universiteto České Budějovice Žemès ūkio fakultetas, Čekija \\ ${ }^{3}$ Slovakijos žemès ūkio universiteto Nitroje Ekonomikos ir vadybos fakultetas
}

\begin{abstract}
Santrauka
Tyrimo tikslas - įvertinti senovinių rūšių kviečiu kokybę ir nustatyti ryšį tarp tešlos reologinių kokybès parametrų ir duonos savybių. Žieminio speltos (Triticum spelta L.) ir dvigrūdžio kviečio (Triticum dicoccon Schrank) grūdų, miltụ bei tešlos reologiniai kokybės parametrai ir duonos savitasis tūris reikšmingai skyrèsi. Nustatyta, kad baltymu kiekis, Zeleny indeksas ir šlapiojo glitimo kiekis buvo reikšmingai didesni (atitinkamai 1,89 \%, 13,0 ml ir 36,1 \%) speltos kviečiu, tačiau glitimo kokybe (glitimo indeksas) buvo didesnè dvigrūdžiu kviečiu. Mixolab rodikliai: dvigrūdžių kviečių baltymų tinklo silpnèjimo greitis (nuolydis $\alpha$ ) ir krakmolo kleisterizacijos greitis (nuolydis $\beta$ ) buvo lëtesni; krakmolo retrogradacija (sukimo momentas C5) buvo mažesnè, o krakmolo kleisterizacijos laikas (T3 - T2) buvo ilgesnis lyginant su speltos kviečių. Pagrindinių komponenčiu analizė parodè, kad speltos ir dvigrūdžiai kviečiai reikšmingai skyrèsi pagal grūdų ir farinografo reologinę kokybę, Mixolab rodiklius ir kepimo testa. Taikant pagrindiniu komponenčiu analizę ir Pirsono koreliacijos koeficienta, dvigrūdžiu kviečiu duonos savitasis tūris buvo labai susijęs su baltymų susilpnèjimu (sukimo momentas C2), farinografo tešlos stabilumu, tešlos formavimosi laiku ir šlapiojo glitimo kiekiu. Ir atvirkščiai, speltos kviečiu duonos savitasis tưris buvo susijęs su Zeleny indeksu ir neigiamai koreliavo su Mixolab baltymų struktūros susilpnėjimo greičiu (nuolydis $\alpha$ ). Šie rodikliai yra patikimiausi prognozuojant speltos ir dvigrūdžių kviečių duonos kepimo kokybę.
\end{abstract}

Reikšminiai žodžiai: kepimo kokybė, pagrindinių komponenčių analizė, reologinė kokybė, Triticum dicoccon, Triticum spelta. 